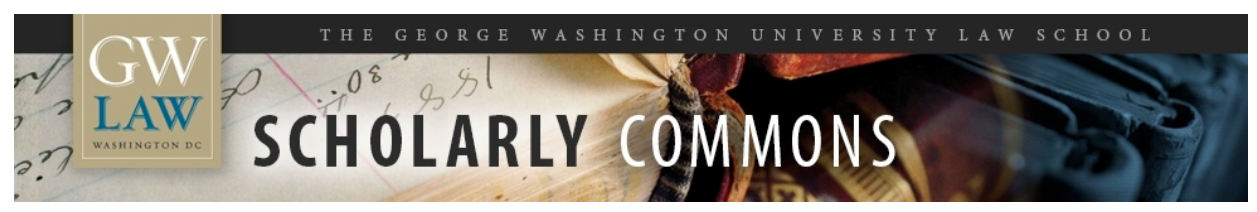

\title{
Religious Exemptions and the Limited Relevance of Corporate Identity
}

Ira C. Lupu

George Washington University Law School

Robert W. Tuttle

George Washington University Law School

Follow this and additional works at: https://scholarship.law.gwu.edu/faculty_publications

Part of the Law Commons

\section{Recommended Citation}

forthcoming 2015 in The Rise of Corporate Religious Liberty (Zoe Robinson, Chad Flanders, and Micah Schwartzman, eds.), Oxford University Press.

This Chapter is brought to you for free and open access by the Faculty Scholarship at Scholarly Commons. It has been accepted for inclusion in GW Law Faculty Publications \& Other Works by an authorized administrator of Scholarly Commons. For more information, please contact spagel@law.gwu.edu. 


\title{
Religious Exemptions and the Limited Relevance of Corporate Identity
}

\author{
Ira C. Lupu \& Robert W. Tuttle ${ }^{1}$
}

\begin{abstract}
Corporate religious liberty appears to be on the rise. The Supreme Court's unanimous decision in Hosanna Tabor v. EEOC (2012) energized sweeping theories about "freedom of the church." The Court's more controversial decision in Burwell v Hobby Lobby Stores, Inc. (2014) determined that for-profit entities may be legally entitled to claim a corporate religious character. Speaking in the language of rights, commentators have vigorously debated the foundations and meaning of these decisions.
\end{abstract}

This chapter argues that these debates are misdirected. The special treatment of religion in American constitutional law does not properly rest on any theory that religious entities enjoy a distinctive set of rights. Instead, the relevant limitation on government arises from the Constitution's Establishment Clause. The governing principle, deeply grounded in history, can best be understood as a prohibition on government involvement - through regulation or financial support - in "purely and strictly ecclesiastical matters." That principle (developed at greater length in our book, Secular Government, Religious People) explains why the government may not decide, for example, who is fit for ministry or which faction within a church is acting in fidelity to its original teachings. The principle applies with equal force to the state's relationship with houses of worship, religious non-profit institutions such as schools or charities, and forprofit businesses whose owners assert a corporate religious character. The only legally relevant differences among these types of organizations should be derived from the likelihood that the principle will be implicated in any particular case.

After reviewing the $19^{\text {th }}$ century underpinnings of this singular approach, and offering pertinent reminders of limits on state financial support for religious teaching, the chapter focuses primarily on the context of employment regulation. Along the way, the chapter addresses concrete questions, such as whether a for-profit business can ever successfully assert a ministerial exception with respect to any of its employees. The answer may surprise you.

\footnotetext{
${ }^{1}$ The authors are both affiliated with George Washington University. Ira C. Lupu is the F. Elwood \& Eleanor Davis Professor Emeritus; Robert W. Tuttle is the David R. and Sherry Kirschner Berz Research Professor of Law and Religion.
} 
In $21^{\text {st }}$ century America, religion tends to be understood in individualistic terms.

Believers typically articulate their faith in terms of a personal relationship with God. Most religious people, however, live out their faith in the company of others. Quite frequently, these associations are organized as corporations - entities in which the body as a whole possesses unified legal personhood. In this chapter, we explore the implications of that legal personhood for the exercise of religion, and more particularly for the question of religious exemptions from general laws.

This exploration occurs against the backdrop of the prominent and recent focus on "the freedom of the church," advocated by a number of scholars in this field. ${ }^{2}$ Although proponents of that concept differ in various ways, they share a commitment to the idea that religious institutions are constitutionally entitled to a zone of freedom in which to govern themselves. Beyond that abstract proposition, however, these proponents tend to ignore crucial questions about the meaning and scope of "the freedom of the church."

First, many offer no guidance for determining which institutions, apart from houses of worship, constitute "the church."” Is a large state-funded non-profit, such as a hospital or social welfare agency, "the church" simply because it has a religious name and origin? Can for-profit entities ever come within the boundaries of "the church"? Who counts as the church when rival factions claim authority? Second, the proponents fail to specify the scope of "internal governance," a category within which proponents claim churches to be autonomous. Are all

\footnotetext{
${ }^{2}$ See chapters XX-XX in this book.

${ }^{3}$ Zoe Robinson offers guidance in What is a "Religious Institution"?, 55 B.C. L. Rev. 181 (2014), but for reasons developed below, we think her approach is deeply flawed.
} 
matters involving corporate structure, employment relations, or uses of church property offlimits to the state?

Moreover, to the extent that "internal governance" conflicts with government regulation, proponents fail to specify how such conflicts should be resolved. ${ }^{4}$ Some who argue for church autonomy emphasize the method of interest balancing, in which the liberty claims of the church are set off against the state's interest in enforcing its laws. ${ }^{5}$ This interest balancing has been formalized in statutes like the Religious Freedom Restoration Act.

We think this emphasis on the "freedom of the church" and the accompanying method of interest balancing are profoundly misguided. As we have explored at length elsewhere, ${ }^{6}$ the story of religious liberty in America is not one of mandatory religion-specific accommodations, or an autonomous domain for "the church." Instead, the roots of religious liberty can be traced to limits on the state's character. A secular government is barred, by its basic identity as expressed in the Establishment Clause, from proclaiming religious truth or adjudicating religious questions. This prohibition certainly creates a zone of non-interference, but the justification for that limit does not arise from the liberty of religious institutions. ${ }^{7}$

\footnotetext{
${ }^{4}$ See Richard Garnett, "The Freedom of the Church": (Towards) an Exposition, Translation, and Defense, 21 J. CONTEMP. LEGAL ISSUES 33 (2013) (dismissing concern about line-drawing as common to all legal doctrines). This is not an adequate response, because one only knows the meaning of a legal norm by understanding how it applies in the context of other norms.

${ }^{5}$ Douglas Laycock, Church Autonomy Revisited, 7 Geo. J.L. \& Pub Pol'y 253 (2009).

${ }^{6}$ Ira C, Lupu \& Robert W. Tuttle, Secular Government, Religious People (Wm. B. Eerdmans Co., 2014)

${ }^{7}$ Religious institutions do enjoy robust rights of association and expression, but only to the extent enjoyed by analogous non-religious institutions. Secular Government, Religious People, chapter 5 .
} 
The misplaced emphasis on the liberty of religious institutions becomes even more problematic when coupled with the use of interest balancing to reconcile the claims of liberty with the concerns of the state. In addition to the notorious indeterminacy of interest balancing as a method, the context of religious rights raises particular problems for that method. Those problems relate directly to the core issues of the state's limited competence. In applying RFRA and its legal analogues, a court often must first decide whether a plaintiff's religious exercise has been "substantially burdened" by government action. That inquiry, if rigorously pursued, would require the court to assess the religious significance of the practice at issue. But such religious determinations are outside the state's competence. ${ }^{8}$

Our approach avoids the problems that arise from using "the freedom of the church" as the driving norm, as well as interest balancing as the method for addressing problems. Our general thesis in this chapter is that corporate entities with asserted religious identities deserve exceptional treatment only with respect to their distinctively religious activities. The state may not participate in or, other than prevention of force or fraud, regulate the distinctive aspects of religious experience: gathering for worship, religious instruction, and spiritual or sacramental celebration of life's major events.

As we explain, religious exercise may take corporate form for a wide spectrum of actions and purposes. At one end of the spectrum sit houses of worship, the paradigmatic form of religious corporation. Such entities tend to be heavily engaged in performance of distinctively religiously activities. No one questions the religious identity of such institutions, although

${ }^{8}$ Id. at chapter 6. 
questions remain about the implications that follow from such recognition. Even houses of worship act in ways that are not religiously distinctive at all. Like many secular entities, houses of worship (for example) build and use parking facilities for their members and guests, and they prepare and serve food at large gatherings they host. These kinds of activities are subject to regulation in the public interest.

In the broad middle of the spectrum are found many organizations that assert religious identities but act in ways considerably removed from the typical functions of houses of worship. These organizations cover an immense range. They include social welfare organizations, such as shelters for the homeless or victims of domestic violence; educational institutions, ranging from pre-schools to research universities; hospitals and assisted living facilities; and many others. Because this middle category includes such a wide variety of activities and purposes, and covers a range in size that runs from tiny neighborhood organizations to multi-billion dollar hospital chains, the category presents an endless variety of questions about how the corporations' religious identity should affect their legal rights and obligations.

The distinctive religious character of these organizations is frequently quite thin. For example, religiously affiliated hospitals are far more like secular private hospitals, or even publicly controlled hospitals, than they are like churches, mosques, or synagogues. Granted, religiously affiliated hospitals may refrain for religious reasons from offering certain services, but in what they do offer, their resemblance to all other hospitals is striking. Religious exemptions for non-profit organizations in this broad mid-range should be directly linked to the religiously distinctive activities they undertake. 
At the other end of the spectrum, highlighted by the decision in Hobby Lobby, are forprofit entities that claim a religious identity, despite their full involvement in the economic marketplace. For-profit entities are strikingly similar to one another in the profit-making motives that animate them, and in the goods and services in which they traffic. Yet even for-profit firms may act in religiously distinctive ways, disconnected from profit motives, such as recognizing a Sabbath or other religious holidays. Although the Administration argued in Hobby Lobby that for-profit corporations are incapable of engaging in the "exercise of religion," the Supreme Court ruled otherwise. ${ }^{9}$ Despite this recognition, the Supreme Court's decision leaves open significant questions about the legal consequences that should flow from the successful assertion of religious identity by a commercial entity. Going forward, the questions after Hobby Lobby will be far less about which entities have rights of religious exercise, and far more about precisely what rights of religious exercise corporate identities may legitimately assert.

In what follows, we analyze questions of corporate identity and religious exemptions along the lines we have suggested in these introductory paragraphs. The extent to which an organization and its activities are distinctively religious will go a long way in explaining when religious exemptions are appropriate. Across the board, such exemptions should be directly related to the religiously distinctive qualities the exemptions are designed to recognize and protect. Religion-specific exemptions that are unrelated to those qualities are rarely more than unjustifiable special privileges for religious entities over their secular counterparts.

\footnotetext{
${ }^{9}$ The Hobby Lobby majority rejected that argument, and only Justices Ginsburg and Sotomayor agreed with it. Justices Breyer and Kagan abstained from decision on the question.
} 


\section{Houses of Worship}

For many traditions, the most significant religious experiences are corporate. The community of faith gathers for prayer, liturgy, and instruction. Individuals may practice aspects of the faith in isolation, but that practice is subordinate to communal experience. Characterizing that religious experience as nothing more than the associational sum of participating individuals' religious experiences misses a crucial element of corporate religious experience. In much of the Christian tradition, for example, the church itself is indispensible for salvation. It is the "Body of Christ," in which members are united with the savior and all other believers, living and dead. From this theological perspective, the believer's union with the sacred community is prior to and distinct from his or her individuated life in the world. Most fundamentally, the church gives life to the believer, not vice versa (as a traditional theory of associations would hold). Because of this theological priority for so many believers, any adequate account of religious freedom should acknowledge the concern about the integrity of religious community.

This theological understanding of religious entities underlies the legal assertion of "church autonomy," an institutional parallel to the idea of personal autonomy, which marks off a zone of freedom from state control. Advocates of this idea seem to believe that the only way the government can show concern for the integrity of the church is to adopt a stance of broad deference. Within the boundaries of "church," authority belongs to those assigned it by religious doctrine. The state shows its respect for the "freedom of the church" by denying that the state has jurisdiction, except in rare instances, over matters that the church deems "internal" to its faith and practice. 
The idea of church autonomy certainly has a long historical pedigree, reaching back to the Gregorian reforms of the middle ages. But broad notions of church autonomy cannot be reconciled with the history and current jurisprudence of "church and state" - the legal relationship between civil authority and houses of worship. From the early years of the republic, the law has treated houses of worship much the same as other legal entities. Although Virginia barred religious congregations from incorporating, other states did not follow suit, and regularly granted corporate charters to houses of worship.

As Professor Gordon's recent work demonstrates, these religious corporations were bound by the same web of state law on matters of tort, property, contract and corporate status as other entities. ${ }^{10}$ For example, general laws of incorporation that arose in the early $19^{\text {th }}$ century in America frequently included a requirement that churches create boards of trustees controlled by lay members of a congregation rather than its clergy. States imposed this condition as a way to limit ecclesiastical power. ${ }^{11}$ Thus, as an historical matter, a general doctrine of "church autonomy" for churches held in corporate form is a complete fiction. Nothing in American state or federal law supports the idea that houses of worship enjoy a presumptive, general immunity from the government's jurisdiction.

The only exceptions to this principle of non-distinctiveness can be found in the contexts of factional disputes within congregations or conflicts about ministerial employment. These

${ }^{10}$ Sarah Barringer Gordon, The First Disestablishment: Limits on Church Power and Property Before the Civil War, 162 U. PA. L. REV. 307 (2014).

${ }^{11}$ States also included limits on the total value of property held by a single religious entity. Id. 
exceptions are best understood as reflections of the state's limited competence in matters of religious doctrine. ${ }^{12}$ During the first half of the $19^{\text {th }}$ century, state courts wrestled with a wide variety of intra-congregational or intra-denominational disputes, in which two or more factions vied for control of a religious body. Although some courts were willing to hear lawsuits that turned on quintessentially theological issues, such as the orthodoxy of certain beliefs about human sinfulness, a significant number of courts expressed uneasiness about such inquiries.

A pair of US Supreme Court cases, decided in 1871 and 1872, vividly illustrates the emerging idea of how the exercise of the state's power to adjudicate should interact with houses of worship. In Watson v. Jones, ${ }^{13}$ the Court considered a dispute that had arisen out of the response of the Presbyterian Church in the United States of America ("PCUSA") to the Civil War. A congregation in Louisville, Kentucky had divided over the issues of slavery and secession. The national denomination ruled that the pro-slavery faction had departed from the doctrine of the PCUSA, and accordingly, that the anti-slavery faction was entitled to control the congregation and its property. The matter ultimately reached the Supreme Court. Applying a version of federal common law, rather than constitutional principles, the U.S. Supreme Court ruled that courts were barred from deciding "strictly and purely ecclesiastical questions." Instead, the dispute must be resolved by deference to the body within the church that has decision-making power over such questions - in this case, that body was the PCUSA.

That Watson v. Jones was about questions that are off limits to the state rather than church autonomy was vividly demonstrated just one year later, in the Court's decision in Bouldin

\footnotetext{
${ }^{12}$ For elaboration see Secular Government, Religious People, chapter 2.

1380 U.S. 679 (1871).
} 
v. Alexander. ${ }^{14}$ A dispute had arisen within a Baptist congregation in the District of Columbia. The founding minister, Rev. Albert Bouldin, had lost the support of a majority of the congregation as well as all four of the congregation's trustees. Bouldin selected a new set of trustees from among his followers and together they proceeded to change the locks on the church and bar the rest of the congregation from entering.

The four originally elected trustees sued to regain the use of the property and to have Bouldin's acts declared unlawful. Bouldin argued that the Supreme Court had no authority over this internal religious dispute. The Court disagreed. Although the Court reaffirmed the previous year's ruling in Watson that the state may not answer certain ecclesiastical questions, the state may nevertheless use ordinary principles of corporate law to determine who has authority to resolve those questions for the church. In Bouldin's case, the Court held that the minister lacked the authority to unilaterally replace the trustees elected by the congregation. Under the congregation's governing documents, the authority to appoint trustees was held by the congregation acting through majority vote.

Thus, by 1872 , federal common law recognized no theory of church autonomy. Rather, the law treated houses of worship precisely as it treated other entities, except when courts were asked to resolve "strictly and purely ecclesiastical questions."

In the second half of the twentieth century, the Supreme Court reinforced and provided constitutional grounding to the principles reflected in Watson and Bouldin. In a series of

1482 U.S. 131 (1872). 
decisions in the 1950s and 1960s about property disputes, the Court limited the authority of courts and legislatures to intervene in the resolution of controversies over ecclesiastical questions. The Court repeatedly ruled that the Religion Clauses of the First Amendment mandated the application of what was a common law principle in Watson v. Jones. ${ }^{15}$

\section{Presbyterian Church in the United States vs. Mary Elizabeth Blue Hull Memorial} Presbyterian Church $^{16}$ provides the starkest example of this constitutional understanding. In the mid-1960's, a number of Presbyterian congregations disagreed with their denomination's position on several theological and social issues, including the ordination of women, support for the civil rights movement, and opposition to the Vietnam War. When the congregations attempted to exit the denomination and retain ownership of the local church property, litigation ensued. The Georgia courts resolved those disputes by invoking a principle of implied trust, under which title to the property depended on which faction was acting in fidelity to the true doctrine of the church. Applying that principle, the jury found in favor of the local congregation. Ultimately, the U.S. Supreme Court reversed and remanded the case, holding that the First Amendment bars civil courts from deciding the kind of question the jury in Georgia had been charged with answering. Instead, the Court ruled, the Georgia courts must find ways to resolve this dispute without considering such ecclesiastical questions.

In the aftermath of Blue Hull, the Court made a series of decisions reaffirming, in constitutional terms, the companion principle from Bouldin v. Alexander. The series culminated

\footnotetext{
${ }^{15}$ Kedroff v. St. Nicholas Cathedral of the Russian Orthodox Church in North America, 344 U.S. 94 (1952); Kreshik v. Saint Nicholas Cathedral, 363 U.S. 190 (1960); Presbyterian Church v. Mary Elizabeth Blue Hull Memorial Presbyterian Church, 393 U.S. 440 (1969). 16393 U.S. 440 (1969).
} 
a decade after Blue Hull in Jones v. Wolf, ${ }^{17}$ which again involved disputes within Presbyterian congregations in Georgia. In an opinion by Justice Blackmun for a five Justice majority, the Court decided that state courts have a choice when presented with disputes over control of church property. These disputes can be resolved either by deferring to the body within the faith community that has authority over the relevant ecclesiastical questions, or by using "neutral principles of law" to examine the legal documents that identify ownership of the disputed property. By invoking the concept of "neutral principles," the Court reaffirmed and gave constitutional warrant to the common law approach of Bouldin - churches are subject to the same norms of contract, property, and trust law as other entities. What remains out of bounds after Jones v. Wolf is what has always been out of bounds - the judicial resolution of "strictly and purely ecclesiastical questions.”

In a pair of cases addressing disputes over ecclesiastical personnel, the Court has applied an identical set of principles about the scope and limits of judicial power. The first of these, Serbian Eastern Orthodox Diocese of America v. Milivojevich (1976), ${ }^{18}$ involved a bishop's challenge to his removal. After the Illinois courts ordered the Serbian Eastern Orthodox Church to reinstate Milivojevich, the Supreme Court reversed. Echoing the themes from its decision in Blue Hull, the Court held that decisions over who is fit to hold ecclesiastical office belong solely to church authorities. Civil courts are constitutionally incompetent to decide who belongs in such a role.

17443 U.S. 595 (1979).

18426 U.S. 696 (1976). 
The Court's decision in Hosanna-Tabor ${ }^{19}$ is a direct outgrowth of this line of decisions. Hosanna-Tabor does not stand for any sweeping "freedom of the church." The decision would never have garnered the votes of all nine Justices if its foundation were so broad, vague in contour, and inconsistent with the past several hundred years of American law. Instead, the “ministerial exception" embraced in Hosanna-Tabor reflects precisely the constitutionally mandated allocation of competence over the question of who is fit for the role of clergy or teacher of the faith. The exception's contours respond directly to the need of religious communities to have full control over who transmits their defining message.

That said, whether a particular position falls within the ministerial exception is a question that civil courts are necessarily qualified to answer. If they were not, the ministerial exception would effectively immunize religious entities from ordinary employment law norms. Churches would always be able to assert that any of their employees function as ministers, and courts would be bound to accept that determination. Instead, the ruling in Hosanna Tabor reserves to courts the authority to decide, in light of the exception's underlying justification, which positions the exception covers. ${ }^{20}$ In this respect, courts' competence to decide which positions are covered is analogous to courts' role in determining which private activities government is forbidden, under the Establishment Clause, to directly fund. In making these judgments, like all others under the Establishment Clause, courts are called upon to draw lines about the limits of the state's power.

19132 S. Ct. 694 (2012).

${ }^{20}$ For a nice example of a close case and the court's proper handling of it, see Archdiocese of Washington v. Moerson, 399 Md. 637; 925 A.2d 659 (2007). 
Thus, Hosanna-Tabor does not recognize any general "freedom of the church." The unanimous opinion in Hosanna-Tabor explicitly left open questions that might arise between a clergy member and her employer under the law of contract and tort. For example, if a rabbi has served a congregation for the past month under an employment contract, and the congregation refuses to pay his salary at the end of the month, the rabbi may sue and recover his unpaid wages. Under general principles of law, the employer-congregation may not assert his unfitness or inadequacy in the role as a defense to his claim, though the employer may discharge him and avoid future wage claims. ${ }^{21}$

Similarly, if the assistant pastor of a congregation alleges that she was sexually assaulted by the congregation's senior pastor, she would certainly have tort claims against the senior pastor, and perhaps also against the congregation for negligent hiring or supervision of the senior pastor. ${ }^{22}$ Like the rabbi's claim for back wages, the assistant pastor's claim of sexual assault would require no inquiry into ecclesiastical questions, and therefore does not implicate the constitutional concerns that justify the ministerial exception.

Another striking example of a religious exemption that cannot be traced to any distinctive limits on the state's authority in religious matters is the "parsonage exemption" from federal income tax. ${ }^{23}$ This provision of the Internal Revenue Code exempts from the income of members of the clergy the value of housing provided by the house of worship that employs them,

\footnotetext{
${ }^{21}$ We explore additional examples of such disputes in Ira C. Lupu and Robert W. Tuttle, Courts, Clergy and Congregations: Disputes Between Religious Institutions and Their Leaders, 7 Geo. J.L. \& Pub. Pol'y 119 (2009).

${ }^{22}$ Ira C. Lupu and Robert W. Tuttle, Sexual Misconduct and Ecclesiastical Immunity, 2004

B.Y.U. L. Rev. 1789.

${ }^{23}$ Internal Revenue Code, 26 U.S.C. § 107.
} 
as well as any housing allowance similarly provided. This treatment of housing and housing allowances deviates sharply from the tax treatment afforded similar benefits provided by employers to other kinds of employees; in all non-clergy cases, such provisions are taxable unless the particular housing provided is for the employer's convenience, such as a university president's residence on campus. Although the parsonage exemption was perhaps once justified by the practice of congregations providing housing attached to the house of worship, thus allowing the minister to be readily reached by parishioners in need, the current scope of the "parsonage exemption" bears little relation to that original situation. Now, clergy may use the parsonage exemption to exclude from income tax a housing allowance that subsidizes a mortgage for a home distant from the place of worship, and quite a bit more valuable than the use of a unit attached to the church. It is no wonder that the exemption has been the subject of recent attack under the Establishment Clause. ${ }^{24}$

Even though the ministerial exception applies to a relatively narrow set of employees, houses of worship have an additional exemption that applies to all employees. Under Section 702, religious institutions are exempt from Title VII's ban on employment discrimination “with respect to the employment of individuals of a particular religion..." In other words, religious institutions, unlike other employers, are free to hire employees who share the institution's faith commitments. $^{25}$

\footnotetext{
${ }^{24}$ Freedom From Religion Foundation v. Lew, __ F.Supp.3d___ (W.D. Wisc. 2013), vacated on standing grounds, _ F.3d _ _ $\left(7^{\text {th }}\right.$ Cir. 2014).

${ }^{25}$ In contrast to the ministerial exception, Section 702 does not exempt religious institutions from Title VII's prohibition on discrimination based on race, sex, or national origin. See Memorandum from Randolph D. Moss, U.S. Assistant Attorney General (Oct. 12, 2000), at 3032 and cases cited therein, archived at http://perma.cc/PAL9-3NE4.
} 
Thus far, in our discussion of the state's distinctive treatment of churches, we have focused on the exemption of religious organizations from legal norms that apply to analogous non-religious entities. Any comprehensive consideration of the distinctive role of houses of worship in the constitutional order, however, must also come to grips with deeply rooted constitutional norms concerning government's financial support for the activities of such organizations. Indeed, in all the talk in this volume about the distinctive rights of autonomous religious institutions, there is precious little attention to this component of the church-state relationship.

We cannot in this space survey all developments in this part of the subject. But we must note both the historical and contemporary concerns about direct government support for houses of worship and those who lead them. Jefferson's Bill for Religious Liberty in Virginia, one of the earliest and most important moves in this direction, explicitly forbade any state support for “any religious worship, place, or ministry whatsoever." ${ }^{26}$ The U.S. Supreme Court has developed a complex body of law about government aid to religious organizations that provide various social services with secular value, such as education or health care. But the Court has consistently affirmed that the government may not fund the core religious activities of worship, proselytizing, or religious instruction. ${ }^{27}$

${ }^{26}$ Va. Const. Art. 1, § 16.

${ }^{27}$ For analysis of a difficult context in which to apply this principle, see Ira C. Lupu \& Robert W. Tuttle, Historic Preservation Grants to Houses of Worship: A Case Study in the Survival of Separationism, 43 B. C. L. Rev. 1139 (2002). See also Locke v. Davey, 540 U.S. 712 (2004) (government had discretion to exclude study of ministry from voucher-type state support). 
The constitutional status of houses of worship thus reveals a distinctive limitation on state power. The state has no legitimate interest in matters that are "strictly and purely ecclesiastical." Thus, government may not decide questions of that character, including who is fit to lead a congregation. In a precisely complementary norm, the government may not subsidize institutions or positions devoted primarily to such matters. Recognizing the reach and limit of these principles will take us a very long way in assessing the constitutional status of other organizations that hold themselves out as religious.

\section{Religious Non-profit Organizations}

The category of religious non-profits encompasses a broad variety of organizations. These entities include institutions engaged in education at all levels, healthcare, social welfare services such as adoption and foster care, and faith-based political advocacy. They relate to houses of worship or religious denominations in a variety of ways, including complete control of the non-profit by a single congregation, affiliation with a denomination, sponsorship by an interfaith coalition, or complete independence from any religious body.

To what extent should the religious identity of these non-profits affect their legal rights or duties? As in the case of houses of worship, the distinctive identity of religious non-profits can have implications for both government regulation and government financial support. The concern for government involvement in the formation of religious character and the proclamation of religious ideas leads to heightened sensitivity, but not to categorical immunity from regulation or exclusion from support. 
Our approach differs markedly from that of scholars who ask whether or not particular institutions have a set of designated characteristics that mark them as religious. ${ }^{28}$ Under such an approach, if the entity satisfies that test, then it enjoys the same broad freedom from regulation as houses of worship; those who fail the test are treated identically with secular non-profits.

We think such a binary approach is unhelpful or worse. Most importantly, this approach suffers from all of the defects of the justifiably discredited concept of "pervasively sectarian" institutions. Under the law as it stood from the early 1970's through at least the late 1990's, pervasively sectarian entities - typically, religious elementary and secondary schools -- were disqualified from receiving direct public support. Such disqualification created a strong incentive for institutions to change or dilute their religious character in order to make themselves eligible for government support. A binary measure for immunity from regulation would likewise create incentives to alter or strengthen religious character as a way to obtain that benefit. Whether the incentives are to weaken or strengthen, in either case the binary approach is an invitation to inauthenticity and manipulation of religious identity.

Even if the institutions are acting in complete good faith, the binary approach requires bureaucrats and judges to make fine-grained determinations about the extent to which an organization has a religious identity. In some contexts, that inquiry is not problematic. For example, IRS officials sometimes do this for the limited purpose of ensuring that an organization

${ }^{28}$ Zoe Robinson, What is a "Religious Institution"?, 55 B.C. L. Rev. 181 (2014). 
claiming to be religious is not a fraud. ${ }^{29}$ However, in the broader context of all legal treatment of non-profit institutions, the binary test requires officials to undertake a much more expansive and less focused examination. Judge McConnell's well-known opinion in the Colorado Christian University case ${ }^{30}$ powerfully explains the constitutional and practical defects of a searching inquiry into the degree of religiosity manifested by the school in its curriculum, hiring and admissions policies, and other expectations for students and faculty.

From our perspective, the most important argument against the binary approach is the absence of a reliable link between the religious character of an institution and the specific claim of legal privilege at issue. Some claims of legal privilege, such as the ministerial exception, have a very strong connection with concerns about the state's limited competence in matters of doctrine and worship. Other claims of legal privilege, however, have no connection with the state's limited competence in such matters. For example, an exemption of religiously based day care centers from state licensing requirements has virtually no connection with those concerns. The licensing of day care facilities, which typically involves health and safety regulations, background checks on caregivers, and occasional inspections, reflects a core exercise of the state's legitimate role in protecting children from risk. The religious identity of any particular day care center should have no bearing on the state's regulatory authority over the center, because the state's concern focuses solely on the well-being of children.

As with houses of worship, the government interacts with religious non-profits in two key areas - employment relationships and government funding. Unlike houses of worship, however,

${ }^{29}$ Church of the Chosen People v. U.S., 548 F. Supp. 1247 (D. Minn. 1982).

${ }^{30}$ Colorado Christian University v. Weaver, 534 F.3d 1245 (10 ${ }^{\text {th }}$ Cir. 2008). 
government interactions with the broader set of religious non-profits pose much more complicated questions in both areas.

\section{Employment Relationships}

Government regulation of employment relationships within religious non-profits raises a variety of constitutional and statutory issues. It seems best to begin with the ministerial exception, which rests on constitutional grounds. As we explained above, the ministerial exception significantly limits government inquiry into religious employers' decisions about certain employees. In houses of worship, the exception applies to employees whose job involves the transmission of faith. For the broader category of religious non-profits, the analysis is exactly the same. A chaplain in a religious hospital would certainly be covered, as would a professor of theology at a seminary.

Beyond the positions that replicate core aspects of the minister's role in a house of worship, religious non-profits may claim the protection of the ministerial exception for other jobs. Courts must evaluate each position, rather than categories of employees, with respect to its relationship to the purposes of the exemption. In close cases, courts should give greater deference to institutions that are directly involved in the articulation of religious ideas or delivery of religious experience, such as schools, counseling services, publishers dedicated to production of religious works, or summer camps. Correspondingly, courts should give less deference to institutions that are predominantly oriented to the delivery of discrete services with obvious secular counterparts, such as healthcare, adoption and other family services, housing, or job 
training. In such service organizations, courts should require strong proof that the role in question involves the explicit transmission of faith, not just a requirement to serve as a role model for the faithful.

Like houses of worship, other religious non-profits also may claim the benefit of Section 702 of Title VII - they may prefer co-religionists with respect to all employment positions. Although the Section 702 exemption may seem uncontroversial with respect to houses of worship, its justification is less apparent when applied to all activities and positions within religious non-profits. Why should a religiously affiliated hospital be free to insist that its accountants or janitors, for example, share the faith commitments of the employer? Indeed, the original version of the Section 702 exemption was limited to employees engaged in religious activities. Congress amended Section 702 in 1972, in response to concerns about line-drawing among various jobs and the extent to which they involved religious activities.

Is the amended Section 702, which applies to all activities of religious non-profits, disproportionate to any reasonable need for exemption from anti-discrimination norms? Although the Section 702 exemption certainly imposes costs on individuals excluded from employment because they do not share the employer's faith, the exemption nonetheless protects legitimate and distinctive concerns of faith institutions. Most importantly, the exemption permits religious non-profits to employ only individuals who share their mission. Seen in that light, the exemption is designed to avoid discrimination against religious organizations rather than respond to a religiously distinctive need for separate legal treatment. The exemption places religious non-profits on equal footing with other cause-oriented organizations. The Democratic Party may 
insist that all its employees be enrolled as voting Democrats; likewise, environmental groups may require all employees to embrace green commitments.

Although the protection afforded by Section 702 is thus closely linked to legitimate interests of religious institutions, a different aspect of employment law shows how protections for religious nonprofits may lack justification under any of the relevant constitutional concerns. Under current law, adjunct faculty at colleges and universities are eligible to form unions and engage in collective bargaining with school administrators. Because of the increasing percentage of non-tenured faculty members in higher education, the right to organize offers an important protection for a large and growing body of workers. However, federal courts have ruled that the National Labor Relations Board (NLRB) lacks the authority to require religious colleges to permit union organizing among, or to engage in collective bargaining with, adjunct faculty. ${ }^{31}$ Those who defend the exemption for religious colleges ground it in the autonomy of religious institutions. Government involvement in the relationship between teachers and administrators, they contend, would violate the schools' "right to be free from government meddling and intrusion in their operations and beliefs." 32

This asserted right can be traced back to the Supreme Court's 1979 decision in NLRB v. Catholic Bishop of Chicago, ${ }^{33}$ which involved an effort to form a union among lay teachers at parochial schools in Chicago. The Court construed the National Labor Relations Act to exclude the employment relationship between lay teachers and church-operated schools. In its rationale

\footnotetext{
${ }^{31}$ University of Great Falls Montana v. NLRB, 278 F. 3d 1335 (D.C. Cir. 2002)

${ }^{32}$ Brief of Cardinal Newman Society, et. al., in Pacific Lutheran University and SEIU Local 925, Before the National Labor Relations Board, available at http://www.alliancealert.org/2014/03/31/newman-society-catholic-colleges-challenge-federallabor-board-in-possible-landmark-case-newman-society/.

33440 U.S. 490 (1979).
} 
for the decision, the Court emphasized the Establishment Clause limitations on government funding of religious schools. At that time, schools that fit the Court's description of "pervasively sectarian" were categorically ineligible for government funding because such funding necessarily carried the risk of "excessive entanglement" between government and religion. The limits on government funding, the Court explained, are necessary to avoid governmental intrusion in decisions about the extent to which religion is incorporated in the curriculum.

Catholic Bishop appropriately extended that categorical logic to the question of NLRB jurisdiction. The Court reasoned that government supervision of the collective bargaining process might be similarly intrusive. What the government may not fund it likewise may not regulate, outside of basic concerns about force and fraud.

Even at that time, however, few colleges and universities fell into the class of "pervasively sectarian" entities, and so most religious colleges qualified for a wide range of government funding programs. ${ }^{34}$ Concerns about excessive entanglement were much less significant in that setting, so the risk of unconstitutional intrusion by the NLRB should have been correspondingly weaker. Now that the Court's Establishment Clause jurisprudence has refocused on the character of specific activities rather than institutions as a whole, those concerns are weaker still. Nonetheless, and despite the NLRB's continued efforts to assert jurisdiction, federal courts continue to hold that the agency has no authority over the relationship between religious colleges and their teachers.

Indeed, most recent litigation involves not the fundamental question of religious schools' exemption, but rather the agency's definition of religious schools. The agency has attempted to

\footnotetext{
${ }^{34}$ See, e.g., Tilton v. Richardson, 403 U.S. 672 (1971).
} 
deploy a narrow definition, akin to the old category of "pervasively sectarian schools." Under that standard, the Catholic Bishop exemption would apply only to schools that demonstrate their religious character by, for example, preferring co-religionists in admission, requiring faculty and students to adhere to certain beliefs, and imposing mandatory religious curriculum. Religious colleges contend that the NLRB's test impermissibly involves the government in what are essentially religious determinations, such as the extent to which religious commitments are present in a school's curriculum.

We have a great deal of sympathy with that particular concern about the NLRB's definitional approach, but not with the religious colleges' broad claim of exemption. The NLRB's test rests on a fundamental error. Whatever justification the Court had for exempting parochial schools in Catholic Bishop, no such rationale can support the current categorical exemption of religious colleges from NLRB jurisdiction. Any concerns about NLRB intrusion in religious education can be handled by regulatory measures far more precise than the categorical exemption of religious higher education. For example, the college could be required to bargain only over a set of indisputably secular conditions of employment, such as wages and hours, benefits, or office space. That more refined treatment of religious colleges, unlike the current institutional exclusion, satisfies the concern for treatment that is closely tailored to distinctive limits on the state's power in dealing with religious matters.

\section{Government Funding}

Over the last two decades, the Supreme Court's jurisprudence on government funding of faith-based institutions has taken a dramatic turn. During the 1970s, the Court adopted a 
categorical prohibition on government aid for "pervasively sectarian" organizations. ${ }^{35}$ Under that formulation, the Establishment Clause barred government support for entities that engage in worship and explicitly religious instruction. As a practical matter, the litigation involved religious primary and secondary schools, usually Catholic. Virtually everyone at the time assumed that the ban encompassed all houses of worship, and as a matter of logic, it also included religious non-profits primarily engaged in faith-intensive forms of social service.

By the early years of the $21^{\text {st }}$ century, however, the Court's interpretation of the Establishment Clause considerably narrowed the prohibition on state funding of religion. In place of a prohibition on aid for "pervasively sectarian" institutions, the Court found two paths to a much wider range of funding for religious non-profits. First, in accord with the general themes of this chapter, the Court shifted from an institutional focus to a more precise prohibition on government funding of "specifically religious" activities. ${ }^{36}$ The category of "pervasively sectarian" entities is now irrelevant as a matter of constitutional law, but the distinction between secular and specifically religious activity remains central. Second, the Court distinguished direct aid from indirect aid, such as voucher-based financing of private schools. ${ }^{37}$ The ban on funding of "specifically religious activities" applies to any program in which the government provides direct support, such as subsidy for the salaries of personnel or payment of overhead expenses. When government aid depends solely on the uncoerced choice of program beneficiaries,

\footnotetext{
${ }^{35}$ Hunt v. McNair, 413 U.S. 734 (1973) is the source of that phrase, but the concept had its genesis in Lemon v. Kurtzman, 403 U.S. 602 (1971). ${ }_{36}$ Mitchell v. Helms, 530 U.S. 793, 846-848 (2000) (O’Connor, J., concurring).

${ }^{37}$ Zelman v. Simmons-Harris, 536 U.S. 639 (2002); see also Witters v. Wash. Dept. of Services for the Blind, 474 U.S. 481 (1986); Zobrest v. Catalina Foothills Sch. Dist., 509 U.S. 1 (1993).
} 
however, the institution to which the beneficiary directs the aid is free to provide services intertwined with specifically religious content.

These two tracks of funding enable and regulate the federal government's initiatives for engaging faith-based institutions in the provision of social welfare services. Originally framed as the Faith Based and Community Initiative of President George W. Bush, and continued as President Obama's program for Faith Based and Neighborhood Partnerships, these efforts guide the use of government resources in social welfare programs by reference to the constitutional norms appropriate to direct and indirect government support. With respect to direct support, federal regulations and guidance materials define the relevant limit on what types of activities may be supported by government grants. ${ }^{38}$ Private institutions that receive these grants must use them only to support services with secular content; social services that include religious content, if offered, must be privately financed and separated by time or place from publicly financed services.

When the government's support is indirect, however, these requirements of separation do not apply. The set of eligible providers may include those who use specifically religious language or concepts to deliver the service. Nevertheless, those who design programs of indirect aid must ensure that all beneficiaries have adequate secular options for receiving the service. The constitutional logic of indirect aid depends on the free choice of beneficiaries between secular and religious options for receiving the service. If the beneficiary has secular choices that

\footnotetext{
${ }^{38}$ See Executive Order 13279, Fundamental Principles and Policymaking Criteria for Partnerships with Faith-Based and Other Neighborhood Organizations, as amended Nov. 17, 2010, § 2(f), available at: http://www.whitehouse.gov/the-press-office/2010/11/17/executiveorder-fundamental-principles-and-policymaking-criteria-partner.
} 
are qualitatively adequate and reasonably accessible, and the beneficiary nonetheless chooses a program with religious content, then the government should not be held responsible for the beneficiary's religious experience.

This shift to the two-path structure of Establishment Clause law represents a significant opening for religious institutions to participate in programs of government-funded social welfare services. Some who assert the "freedom of the church," however, believe that the current structure remains unduly restrictive. By forbidding direct aid to faith-integrated programs, they claim, the government discriminates against religious providers who are not willing or able to segregate secular and religious elements of their programs, as well as those whose services do not fall within programs of indirect financing.

What these critics see as discrimination, we view as appropriate and focused concern for important constitutional values. Our counterarguments are grounded in the fundamental character of civil government, as well as respect for the dignity of program beneficiaries. As we explain in our book, ${ }^{39}$ a core characteristic of the American experiment has been its commitment to the secular character of civil authority. Among the most important aspects of that character is the idea that civil government should not use religion as a means to the state's own ends, however laudable those goals might be. ${ }^{40}$

\footnotetext{
${ }^{39}$ See Chapter 1 of Secular Government, Religious People.

${ }^{40}$ This limitation does not preclude all relationships between government and faith-intensive programs of service, but such programs are subject to special limitations on funding and concerns about the free choice of beneficiaries. In the absence of such protections, the government is fairly held responsible for the religious indoctrination of program beneficiaries. See $i d$., Chapter 3.
} 
The concern for the dignity of program beneficiaries, by contrast, is recognized - or at least conceded - by even the most religion-friendly architects of the relationship between government and faith-based service providers. Put most simply, programs that receive direct government aid may not condition the delivery of government-financed services on the willingness of beneficiaries to engage in religious activities. Any specifically religious activities offered by such programs must be distinct from the government-funded services, and completely voluntary for beneficiaries. To require less than that would be to deny the fundamental dignity of aid beneficiaries, by exposing them to religious coercion as the price of receiving public assistance.

Advocates of a strong "freedom of the church" have been especially concerned about the possibility that receipt of government support will bring limitations on providers' right to prefer co-religionists in delivering those services. Prior to the Faith-Based Initiative, most federal agencies required all grant recipients to refrain from engaging in various forms of employment discrimination, including based on religion. The agencies provided no exception to religious grantees. Thus, any religious entity that received public funding was required to agree not to prefer co-religionists in employment. The rules that emerged under the Faith Based Initiative directly and immediately address this concern. Unless funding statutes require otherwise, the rules assure faith-based grant recipients that their freedom to prefer co-religionists would be preserved.

\section{For-Profit Corporations}


As we explained at the beginning of the chapter, corporate entities, including businesses, have the legal right to adopt and manifest a religious identity. The decision to claim a religious identity belongs to those who have legal control over the entity. Others have unpacked the complex issues of corporate law embedded in that decision, including questions concerning how disagreements among owners, or related issues of control, affect the entity's claim of a religious identity. But, from our perspective, that claim is a private matter to be resolved among the corporation's constituents by ordinary legal norms.

Our focus is limited to the implications that should follow from that assertion. In terms of expressive freedom, the law gives business owners significant latitude to use corporate assets to advance religious messages, even if those messages have no direct relationship to the goods or services provided. For example, businesses can display religious texts or give customers religious materials. Moreover, businesses are free to emphasize the role that religious values play in their corporate practices. Hobby Lobby closed on Sundays; many businesses owned by observant Jews have long closed on Saturdays and other holy days. Businesses may emphasize certain music, videos, or publications that have religious themes, and refuse to carry others that they deem inappropriate for religious reasons.

From the law's perspective, a corporation's assertion of a religious identity will only matter when the manifestations of that identity collide with the entity's legal duties to employees, customers, and others. The most frequent locus for these collisions is the employment relationship, and we turn to that first, before considering relationships with customers. 


\section{Employees}

In what ways might the religious identity of a for-profit corporation make a difference for its employees? Some businesses have argued that, in order to fully embrace their religious identity, employment must be restricted to those who share the faith commitments of the business owners. ${ }^{41}$ Other businesses have required employees to participate in religious observances during the work day, and have disciplined employees who fail to do so. These employers' practices would seem obviously to violate Title VII, which prohibits employment discrimination based on religion. But, in these instances, the employers have argued that they fall within Title VII's exemption for religious entities. The exemption reads:

This subchapter shall not apply to ... a religious corporation, association, educational institution, or society with respect to the employment of individuals of a particular religion to perform work connected with the carrying on by such corporation, association, educational institution, or society of its activities.

The governing law interpreting this exemption limits it to entities that are "primarily religious" in their character and activities. This limitation applies to both non-profit and for-profit entities. Indeed, the EEOC has ruled ineligible a number of prominent non-profits that have religious

${ }^{41}$ McClure v. Sports \& Health Club, Inc., 370 N.W.2d 844 (Minn. 1985). 
origins, affiliations, and titles, because the organizations' activities no longer reflected significant religious content. ${ }^{42}$

Although for-profit entities are theoretically capable of meeting the "primarily religious" standard, no judicial decision has ever extended the exemption to a for-profit business. The leading case, EEOC v. Townley Engineering Company, ${ }^{43}$ interpreted "primarily religious" in terms of the content of the business. Because the company manufactured mining equipment, the court ruled that the productive activity of the business had no relationship with religion, even if the owners engaged in various forms of religious expression in the workplace.

The Supreme Court's decision in Hobby Lobby may call into question the EEOC's effective exclusion of businesses from the class of "religious corporations" under § 702. A firm like Hobby Lobby that wanted to hire only co-religionists could argue either that it falls under the definition of "religious corporation" in $\S 702$, or that the Title VII bar on religion-based discrimination imposes a substantial burden on their religious exercise. ${ }^{44}$ If either argument succeeded, the class of entities - including businesses - legally permitted to prefer co-religionists in employment would expand considerably.

\footnotetext{
${ }^{42}$ See EEOC v. Kamehameha Schools/Bishop Estate, 990 F.2d 458, 461 (9th Cir. 1993); Fike v. United Methodist Children's Home, Inc., 709 F.2d 284, 287 (4th Cir. 1983). See generally EEOC Informal Discussion Letter, Title VII - Religious Organization Exception, December 28, 2007 , http://www.eeoc.gov/eeoc/foia/letters/2007/religious_organization_exception_dec_28_2007.html ${ }^{43} 859$ F.2d 610 (9th Cir. 1988).

${ }^{44}$ This would be a RFRA claim against application to the employer of Title VII's prohibition on religious discrimination.
} 
We think this would be a profound mistake. Recall that the original version of $\S 702$ exempted religious organizations from Title VII's ban on religious discrimination only with respect to employees that are directly engaged in religious activities. Congress broadened the exemption to avoid line-drawing problems, but in doing so has already removed a significant number of non-religious jobs from the protections of Title VII.

Broadening the number of exempted employers - and jobs - has two problematic consequences. First, it further limits employment opportunities on the basis of religion, and thus conflicts with one of the central purposes of Title VII, which is designed to reduce status-based barriers to employment. Second, permitting even more employers to select employees based on religion would increase religion-based segregation within society, as what used to be religiously diverse workplaces became religiously insular. We firmly believe that religious equality in the labor market has promoted civic harmony, and helped to mitigate the divisiveness and conflict that have plagued other parts of the world.

The traditional limitation of the $\S 702$ exemption to entities that are "primarily religious" in their character and activities seems to us a much better way of reconciling the competing concerns. In applying that standard, the EEOC and courts should be open to the possibility of for-profit employers qualifying as "primarily religious." The best candidates for that status would be businesses whose productive activities involve goods or services that have thickly religious content. For example, a store exclusively devoted to selling books and other goods linked to a particular faith tradition should qualify as "primarily religious." 
Even if an entity does so qualify, it still may enjoy some legal protection for employment decisions that affect the religious character of the organization. If a for-profit corporation hires an employee specifically to advance its religious mission, that employee may well fall within the scope of the ministerial exception. To the best of our knowledge, all reported decisions that involve the ministerial exception have arisen in the context of a house of worship or a religious non-profit entity. But we see no reason in principle that a for-profit entity would be barred from raising the ministerial exception.

For example, imagine that Hobby Lobby hires a corporate chaplain who is an ordained minister in the owners' faith tradition. The chaplain is hired to provide counseling for employees, as well as regular worship and other religious services for the owners and any employees who want to participate. ${ }^{45}$ What if the owners dismiss the chaplain for promoting theological beliefs inconsistent with the beliefs of the owners, and the chaplain files a claim under Title VII, alleging discrimination based on religion?

Or imagine that religious authorities required kosher or halal butcher shops to employ a full-time religious inspector, who would constantly monitor the practices of other employees in the shop and resolve any disputed questions of religious law. ${ }^{46}$ If such an inspector filed a discrimination claim against his butcher shop employer, could the shop invoke the ministerial exception?

\footnotetext{
${ }^{45}$ Employees who do not want to attend such worship services must be excused, and may not suffer any employment consequences from their refusal to participate. See EEOC v. Townley Engineering, 859 F.2d 610, 618 (9th Cir. 1988).

${ }^{46}$ See Shaliehsabou v. Hebrew Home of Greater Washington, 363 F.3d 299 ( $4^{\text {th }}$ Cir. 2004).
} 
The best argument against allowing the owners to assert the ministerial exception is that expanding the doctrine to encompass for-profit entities presents a problem of the slippery slope. Could the employer then designate a significant portion of the workforce as "missionaries," who spend most of their day performing ordinary tasks, but also have some responsibility for "ministerial duties" such as leading prayer or sharing religious messages with customers? Recall that Cheryl Perich, the plaintiff in Hosanna-Tabor, spent the bulk of her work hours in secular teaching and related duties. The predominance of secular tasks did not remove Perich from the class of "ministerial" employees. But that conclusion reflects an implicit judgment about the employer, a religious school. Given that the school's mission included inculcation of the faith, the Supreme Court appropriately deferred to the school's decision about how to allocate responsibilities for leading the children in prayer and worship.

For entities that are not engaged in "primarily religious" activities, however, we would expect the ministerial exception to take on a far more limited character. Where the Court in Hosanna Tabor substantially deferred to the religious entity's allocation of responsibilities, a business entity should only be able to claim the exception with respect to positions that have exclusively and explicitly religious duties. Moreover, the employer should clearly communicate to the employee both the religious character of the duties and the legal consequences that follow from that ministerial character.

\section{Customers}


A religious business is also likely to manifest its religious identity in relationships with customers. We have written about the complicated issues that arise when business entities decide, on religious grounds, not to serve particular classes of customers. ${ }^{47}$ The most prominent recent examples include some businesses' refusal to serve same-sex couples, or to provide goods for use at same-sex weddings. We think that the public character of these businesses, the sweep of goods and services that such refusals might cover, and the risks of both material and stigmatic harm to same sex couples counsel strongly against exemptions of such businesses from relevant anti-discrimination laws.

A very different set of issues arises when the government attempts, or is asked by consumers, to regulate the religious quality of goods sold by a business. When a business advertises that its meat is " $100 \%$ kosher," should a court or government agency be able to decide whether that claim is truthful? This question does not implicate the religious freedom of merchants. Instead, this issue focuses on the government's competence to articulate and apply religious standards.

In a variety of contexts, courts have quite appropriately held that the government has no authority to declare what the standards of religious dietary law are, or whether a particular merchant has complied with those standards. Attempts by several states to create government

${ }^{47}$ Ira C. Lupu \& Robert W. Tuttle, Same Sex Equality and Religious Freedom, 5 Northwestern J. L. \& Soc. Pol'y 274 (2010). 
agencies that would enforce kosher fraud laws have been held unconstitutional under the Establishment Clause. ${ }^{48}$

By contrast, the state should be able to adjudicate whether specific factual assertions by merchants are truthful. Such assertions include what animal, or part of an animal, particular meat comes from, as well as whether the meat has been inspected and approved by a specific religious authority. These are questions of objectively verifiable fact; neither involves the content of religious norms, or appraisals of fidelity to them. Questions of that type are off-limits to the government, even if they arise in a context where commercial fraud is a possibility. States must find secular avenues for policing such fraud, and leave religious policing to private parties, including customers and religious authorities.

\section{Conclusion}

As readers of this volume know, a number of other scholars in the field are drawn to sweeping generalizations about "church autonomy" and "freedom of the church." In past writing, they have been willing to leave to another day the hard questions raised by their approach - in particular, who qualifies as "the church," and in what specific contexts should the state treat "the church" as autonomous. We think this failure to attend to particular and difficult questions is the path to over-broad regimes of religious exemption and unjustified norms of religious privilege.

${ }^{48}$ See Mark Popovsky, The Constitutional Complexity of Kosher Food Laws, 44 Columbia J. L. \& Soc. Probs. 75, 89-93 (2010) (citing cases from New Jersey, Maryland, and New York) 
Religious exemptions are not a function of private freedoms, of "the church" or otherwise. Instead, they arise primarily from an understanding of what government may not appraise, decide, or support. Corporate identity is connected to this understanding only because of the likelihood of, and frequency with which, such questions will arise. Whether as house of worship, religious non-profit, or religiously identified for-profit, the corporate character of religious identity serves only as a rough marker for the need to be sensitive to the appearance of such questions, and can serve as a guide to reasoning about them at the margin. At the most fundamental level, what is off-limits to the state is a constant, and does not change by virtue of private choices to express religious identity in a variety of forms, institutional, associational, or otherwise. 